\title{
EFEKTIVITAS MEDIA LAGU DALAM PEMBELAJARAN MENULIS CERPEN DI KELAS XI IPA SMA SWASTA TALAGA BESAR
}

\author{
Kosilah \\ Prodi Pendidikan Guru Sekolah Dasar, Fakultas Keguruan dan Ilmu Pendidikan \\ Universitas Muhammadiyah Buton, Jl. Betoambari No. 36 Baubau. \\ E-mail: kosilah81@gmail.com
}

\begin{abstract}
Abstrak
Penelitian ini bertujuan untuk mendeskripsikan keefektifan media lagu dalam pembelajaran menulis cerpen bagi siswa kelas XI IPA SMA Swasta Talaga Besar. Hasil penelitian menunjukan bahwa ada perbedaan antara siswa yang menulis cerpen dengan menggunakan media lagu dengan siswa yang menulis cerpen tanpa menggunakan media lagu . Ini dibuktikan oleh perbedaan perolehan nilai rata-rata yaitu 8,8 untuk yang menggunakan media lagu dan 7,6 bagi yang tidak menggunakan media lagu. Pengolahan data penelitian yang dilakukan peneliti dengan nilai $t$, yang menunjukkan bahwa $t$ hitung bernilai 1,78 sedang harga $t$ tabel menunjukkan 1,67 pada taraf signifikansi $5 \%$ dengan taraf kebebasan (db) 58. Jadi harga $t$ hitung lebih besar daripada harga $t$ tabel. Dengan demikian, dilihat dari hasil perhitungan menunjukkan bahwa media lagu efektif diterapkan dalam pembelajaran menulis cerpen oleh siswa kelas XI IPA SMA Swasta Talaga Besar.
\end{abstract}

Kata Kunci: Keefektifan, Media lagu, Cerpen.

\begin{abstract}
This study aims to describe the effectiveness of song media in learning to write short stories for students of class XI IPA in Big Talaga Private High School. The results showed that there were differences between students who wrote short stories using song media with students who wrote short stories without using song media. This is evidenced by the difference in the acquisition of an average value of 8.8 for those who use song media and 7.6 for those who do not use song media. Research data processing conducted by researchers with a value of $t$, which indicates that the $t$ count is 1.78 while the price of $t$ table shows 1.67 at the significance level of $5 \%$ with the level of freedom $(d b) 58$. So the price of $t$ count is greater than the price $t$ table. Thus, judging from the results of the calculation shows that the effective song media is applied in learning to write short stories by students of class XI IPA in Big Talaga Private High School.
\end{abstract}

Keywords: Effectiveness, song media, short stories. 


\section{SANG PENCERAH}

Volume 4, Nomor 2, Agustus 2018, Hlm. 21-27

Kosilah: Evektifitas Media Lagu dalam Pembelajaran ...

\section{Pendahuluan}

Pendidikan merupakan faktor yang sangat penting dalam kehidupan manusia dan tidak dapat dipisahkan antara satu dengan yang lainnya. Karena itu, dalam setiap aspek kehidupan manusia baik secara pribadi, kelompok, keluarga maupun dalam berbangsa dan bernegara, pendidikan wajib dilaksanakan. Sehubungan dengan itu, segala proses pendidikan selalu diarahkan untuk dapat menyediakan atau menciptakan tenaga-tenaga terdidik bagi kepentingan bangsa, negara dan tanah air.

Salah satu faktor yang sangat mempengaruhi mutu pendidikan adalah guru. Guru sebagai seorang pendidik dan sebagai orang yang memberi ilmu pengetahuan kepada anak didik harus betulbetul memahami kebijakan-kebijakan pendidikan. Dengan pemahaman itu guru memiliki landasan-landasan berpijak dalam melaksanakan tugas di bidang pendidikan. Namun perlu dipahami bahwa guru memang bukanlah satu-satunya sumber belajar, walaupun tugas, peranan, dan fungsinya dalam proses belajar mengajar sangat penting. Prestasi yang dicapai anak didik tidak hanya dipengaruhi oleh tingkat pengetahuan guru terhadap materi pelajaran yang akan diajarkan, tetapi yang juga ikut menentukan adalah metode mengajar dan media pembelajaran yang digunakan. Penggunaan media dapat membantu siswa untuk dapat lebih memahami benda-benda yang abstrak.

Tujuan pembelajaran sastra di sekolah adalah agar siswa mempunyai pengalaman berekspresi sastra. Pengalaman berekspresi sastra ini dilakukan sebagai kegiatan mengembangkan daya imaji, rasa, dan daya cipta. Menulis cerpen merupakan salah satu pengejawantahan dalam mengekspresikan pengalaman bersastra siswa.Keterampilan menulis sebagai salah satu bagian dari empat komponen keterampilan berbahasa mempunyai peranan penting di dalam kehidupan manusia. Oleh karena itu, keterampilan menulis sangat penting untuk dikuasai. Dengan menulis, seseorang dapat mengungkapkan pikiran dan gagasan untuk mencapai maksud dan tujuan.

Kegiatan menulis merupakan suatu ciri dari orang terpelajar. Kegiatan menulis merupakan aktivitas yang tidak terpisahkan dari kegiatan belajar sejak SD sampai perguruan tinggi, yaitu sejak anak dapat mengeja, membuat kalimat, sampai mahasiswa menyusun laporan praktikum dan menyusun makalah. Salah satu pembelajaran menulis yang penting diajarkan kepada siswa SMA adalah menulis narasi yang mengandung unsur imajinasi. Salah satu bentuk narasi adalah sugestif cerita pendek (cerpen). Menulis semacam ini dinamakan menulis kreatif. Menulis merupakan suatu pekerjaan yang sulit. Kegiatan menulis bukanlah sekedar menggoreskan atau menggambarkan huruf, tetapi menulis benar-benar melibatkan banyak aspek, baik aspek bahasa maupun nonbahasa, termasuk di dalamnya pikiran penulis itu sendiri. Penulis membutuhkan daya imajinasi yang kuat.

Budaya menulis bagi kalangan akademisi, masih saja merupakan fenomena yang terbelakang, walaupun diketahui bahwa pembelajaran menulis itu merupakan bagian yang esensial dalam pembelajaran bahasa dan sastra Indonesia. Pada kenyataannya pembelajaran menulis kurang mendapat perhatian. Pembelajaran menulis mestilah dirancang dan dilaksanakan secara terprogram sehingga memiliki arah dan tujuan yang jelas. Pilihan pendekatan pembelajaran menulis perlu didasari pertimbangan edukatif dalam rangka pengembangan aspek kognitif, afektif, dan psikomotorik. Oleh karena itu, ragam bahasa, topik atau tema yang diangkat dalam kegiatan pembelajaran menulis pun perlu diseleksi atau dipilih sesuai dengan kebutuhan pembelajarannya.

Pembelajaran membaca dan menulis yang dulu merupakan pelajaran dan latihan 


\section{SANG PENCERAH}

Volume 4, Nomor 2, Agustus 2018, Hlm. 21-27

Kosilah: Evektifitas Media Lagu dalam Pembelajaran ...

pokok, kini kurang mendapat perhatian, baik para siswa maupun guru. Pembelajaran menulis tidak ditangani sebagaimana mestinya. Para siswa dan guru lebih memfokuskan kegiatan pelajaran pada materi-materi teoritik yang mengarah pada keberhasilan siswa dalam mencapai nilai UN.

Kurang berhasilnya pembelajaran menulis, khususnya menulis cerpen, juga dipengaruhi oleh segi afektif siswa selaku pembelajar yang kurang merespon positif kegiatan menulis. Selain itu, pengajaran sastra di sekolah masih dilakukan dengan cara tradisional. Alasan lain bahwa pengajaran sastra di sekolah terhambat karena siswa dalam mempelajari Bahasa Indonesia masih dangkal pengetahuannya tentang sastra. Salah satu langkah positif yang dapat dilakukan adalah dengan menggunakan media atau alat peraga. Media atau alat peraga yang dapat digunakan oleh guru adalah lagu. Selain dapat membantu siswa untuk menulis, hal ini juga dapat menarik perhatian dan mempercepat pemahaman siswa dalam menerima pelajaran.

Peneliti memilih kelas XI IPA SMA Swasta Talaga Besar sebagai objek penelitian karena selain materi menulis kreatif narasi (cerpen) terdapat dalam Kurikulum Tingkat Satuan Pendidikan pada kelas XI SMA yang telah diterapkan di sekolah tersebut dan sepanjang pengetahuan penulis, penelitian tentang keefektifan media lagu dalam pembelajaran menulis cerpen belum pernah diadakan di sekolah tersebut sebelumnya. Sehubungan dengan uraian di atas, maka peneliti bermaksud melakukan penelitian untuk melihat keefektifan media lagu dalam pembelajaran menulis cerpen. Penelitian yang dimaksud adalah keefektifan media lagu dalam pembelajaran menulis cerpen siswa kelas XI IPA SMA Swasta Talaga Besar. Berdasarkan deskripsi di atas, fokus penelitian ini adalah apakah media lagu efektif diterapkan dalam pembelajaran menulis cerpen bagi pelajar pada siswa kelas XI IPA SMA Swasta Talaga Besar?

Tujuan peneltian ini untuk mengetahui keefektifan media lagu dalam pembelajaran menulis cerpen siswa kelas XI IPA SMA Swasta Talaga Besar.

\section{Metode Penelitian}

Salah satu pembelajaran menulis yang penting dalam mencipta sebuah karya sastra, perlu digunakan media pembantu yakni media lagu. Kebanyakan siswa kurang mampu untuk menuangkan ide mereka ke dalam tulisan, kurangnya kemampuan untuk menyusun secara apik konsep-konsep yang ada dalam pikiran mereka, serta macam-macam alasan yang diberikan Untuk mengukur keberhasilan menulis siswa dengan menggunakan menggunakan dua jenis kelas yaitu, kelas kontrol dan kelas perlakuan. Pada kelas kontrol penulisan cerpen tidak menggunakan media lagu. sedangkan, kelas perlakuan adalah siswa menulis cerpen dengan mengunakan media lagu. Dari hasil karangan siswa dalam menulis cerpen melalui media lagu kemudian dianalisis dengan menggunakan kriteria penilaian cerpen. Setelah dianalisis, barulah akan didapatkan hasil, yakni efektif atau tidak penggunaan media lagu dalam pembelajaran menulis cerpen. Penelitian ini difokuskan pada keefektifan media lagu dalam pembelajaran menulis cerpen siswa kelas XI IPA SMA Swasta Talaga Besar.

Pada dasarnya, penelitian ini adalah penelitian eksperimen control group design karena melibatkan dua kelompok, yaitu kelompok/kelas eksperimen (menulis cerpen dengan menggunakan media lagu) dan kelompok/kelas kontrol (menulis cerpen dengan menggunakan teknik/strategi ceramah berupa penjelasan tentang hal-hal yang berkaitan dengan cerpen), sejalan dengan pendapat Tarigan (1993:102) "paling sedikit dua kelompok termasuk/tercakup dalam telaah; kelompok 


\section{SANG PENCERAH}

Volume 4, Nomor 2, Agustus 2018, Hlm. 21-27

Kosilah: Evektifitas Media Lagu dalam Pembelajaran ...

pengawas dan kelompok eksperimental". Dengan populasi sebanyak 119 siswa, maka peneliti mengambil sampel penelitian $25 \%$ da populasinya, maka sampel penelitian ini adalah 30 orang. Adapun Teknik pengumpulan data dalam penelitian ini adalah tes tertulis dengan melalui dua tahap yakni tahap pertama siswa menyimak lagu "Bunda" oleh Melly Goeslaw. Sedangkan, pada kelas kontrol siswa menyimak peneliti/guru menjelaskan teknik menulis cerpen tanpa menggunakan atau memperdengarkan lagu, dan pada tahap kedua adalah siswa diberikan tes, tes yang diberikan di sini adalah membuat cerpen yang bertemakan Ibu. Hasil cerpen yang dibuat diperiksa oleh dua orang pemeriksa dengan skor maksimal 100.

\section{Pembahasan}

Hasil penelitian ini akan dihitung berdasarkan teknik analisis data yang telah dijelaskan pada penjelasan sebelumnnya di karenakan penelitian ini adalah penelitian eksperimen yang dikuantitatifkan. Penyajian hasil analisis terdiri atas dua kategori, yakni penyajian data nilai siswa yang menggunakan media lagu dalam menulis cerpen dan hasil analisis data nilai siswa tanpa menggunakan media lagu dalam menulis cerpen. Adapun penyajiannya dapat dilihat sebagai berikut:

\section{Deskripsi Data Kelas Eksperimen}

Pada kelas eksperimen yaitu kelas XI IPA 2 terdapat 30 siswa. Dari 30 orang siswa tidak ada yang memperoleh skor 100 sebagai skor maksimal. Skor tertinggi yang dicapai oleh siswa adalah 91 yang dicapai oleh 6 orang dan skor terendah yang dicapai siswa adalah 82 yang diperoleh 1 orang siswa. Perolehan skor siswa dari skor tertinggi sampai skor terendah secara berurutan dapat diuraikan sebagai berikut: skor tertinggi yang dicapai siswa yaitu 91 yang diperoleh oleh 6 orang (20\%); sampel yang memperoleh skor 90,5 berjumlah 1 orang (3,3\%); sampel yang memperoleh skor 89,5 berjumlah 1 orang (3,3\%); sampel yang memperoleh skor 89 berjumlah 2 orang $(6,6 \%)$; sampel yang memperoleh skor 88 berjumlah 6 orang (20\%); sampel yang memperoleh skor 87,5 berjumlah 2 orang (6,6\%); sampel yang memperoleh skor 87 berjumlah 4 orang (13,3\%); sampel yang memperoleh skor 86 berjumlah 1 orang (3,3\%); sampel yang memperoleh skor 85 berjumlah 2 orang $(6,6 \%)$; sampel yang memperoleh skor 83,5 berjumlah 2 orang $(6,6 \%) ; 82$ sebagai skor terendah sebanyak 1 orang $(3,3 \%)$.

Adapaun deviasi standar data tersebut adalah 15. Selanjutnya, mean dan deviasi strandar yang telah diperoleh ditransfer ke dalam konversi angka berskala 1-10, skor mentah siswa dapat dikonversi ke dalam nilai berskala 1-10 skaligus dapat pula diketahui nilai, frekuensi, dan persentase tingkat kompetensi siswa kelas XI IPA 2 SMA Swasta Talaga Besar dalam menulis cerpen dengan menggunakan media lagu, seperti tampak pada Tabel 1 berikut ini.

\section{Tabel 1 Frekuensi dan Persentase Nilai Kompetensi Siswa Kelas Eksperimen}

\begin{tabular}{ccc}
\hline Skala Nilai & Frekuensi & Persentase $(\%)$ \\
\hline 10 & 0 & 0 \\
9 & 25 & 83,3 \\
8 & 5 & 16,7 \\
7 & 0 & 0 \\
6 & 0 & 0 \\
5 & 0 & 0 \\
4 & 0 & 0 \\
3 & 0 & 0 \\
2 & 0 & 0 \\
1 & 0 & 0 \\
\hline Jumlah & 30 & 100 \\
\hline
\end{tabular}

Berdasarkan Tabel tersebut, diperoleh gambaran bahwa nilai yang diperoleh sampel bervariasi. Sebanyak 25 orang $(13,3 \%)$ yang memperoleh nilai 9 sebagai nilai tertinggi; sampel yang 


\section{SANG PENCERAH}

Volume 4, Nomor 2, Agustus 2018, Hlm. 21-27

Kosilah: Evektifitas Media Lagu dalam Pembelajaran...

memperoleh nilai 8 sebagai nilai terendah sebanyak 5 orang $(16,7 \%)$. Denga demikian diketahui bahwa nilai rata-rata $(\bar{X})$ siswa kelas eksperimen (pemberian media lagu) adalah 8,8 yang diperoleh dari rumus:

$$
\begin{aligned}
& \bar{X}=\frac{\sum X}{N} \\
& \bar{X}=\frac{265}{30} \\
& \bar{X}=8,8
\end{aligned}
$$

Hasil nilai rata-rata tersebut dapat ditransformasikan ke dalam tabel klasifikasi kompetensi siswa kelas XI IPA 2 SMA Swasta Talaga Besar dalam menulis cerpen dengan menggunakan media lagu dalam pembelajaran bahasa indonesia. Nilai rata-rata kompetensi menulis cerpen dengan menggunakan media lagu siswa kelas eksperimen dikategorikan tinggi. Hal ini terlihat pada tabel di atas yang menunjukkan bahwa nilai 8,8 berada pada rentang nilai $8,0-$ 8,9 (kategori tinggi).

\section{Deskripsi Data Kelas Kontrol}

Pada kelas kontrol yakni kelas XI IPA 1, berjumlah 30 orang siswa. Dari hasil analisis data tes prestasi belajar bahasa Indonesia dalam hal ini menulis cerpen dan dianalisis maka diperoleh gambaran, yaitu: tidak ada siswa yang mampu memperoleh skor 100 sebagai skor maksimal. Skor tertinggi yang didapatkan pada kelas kontrol adalah 90 yang dicapai oleh 1 orang. Sedangkan, skor terendah 70 dicapai oleh 1 orang. Perolehan skor siswa dari skor tertinggi sampai skor terendah secara berururtan dapat diuraikan sebagai berikut: skor tertinggi yang diperoleh oleh siswa yaitu sampel yang memperoleh skor 90 berjumlah 1 orang $(3,3 \%)$; sampel yang memperoleh skor 86 berjumlah 3 orang $(10 \%)$; sampel yang memperoleh skor 84,5 berjumlah 1 orang (3,3\%); sampel yang memperoleh skor 84 berjumlah 1 orang
(3,3\%); sampel yang memperoleh skor 83 berjumlah 1 orang $(3,3 \%)$; sampel yang memperoleh skor 82 berjumlah 1 orang (3,3\%); sampel yang memperoleh skor 80,5 berjumlah 1 orang (3,3\%); sampel yang memperoleh skor 80 berjumlah 3 orang $(10 \%)$; sampel yang memperoleh skor 79 berjumlah 1 orang (3,3\%); sampel yang memperoleh skor 78,5 berjumlah 1 orang (3,3\%); sampel yang memperoleh skor 77,5 berjumlah 1 orang (3,3\%); sampel yang memperoleh skor 77 berjumlah 1 orang (3,3\%); sampel yang memperoleh skor 76,5 berjumlah 1 orang (3,3\%); sampel yang memperoleh skor 75 berjumlah 5 orang $(16,7 \%)$; sampel yang memperoleh skor 74 berjumlah 1 orang $(3,3 \%)$; sampel yang memperoleh skor 72 berjumlah 1 orang (3,3\%); dan sampel yang memperoleh skor 70 sebagai skor terendah berjumlah 1 orang $(3,3 \%)$.

Dengan demikian, deviasi standar data tersebut adalah 15. Selanjutnya, mean dan deviasi strandar yang telah diperoleh ditransfer ke dalam konversi angka berskala 1 - 10. Dari hasil sampel sebanyak 4 orang $(13,3 \%)$ yang memperoleh nilai 9 sebagai nilai tertinggi; sampel yang memperoleh nilai 8 sebanyak 10 orang (33,3\%); sampel yang memperoleh nilai 7 sebanyak 16 orang $(53,3)$. Berdasarkan perolehan nilai dan persentase di atas, dapat diketahui jumlah nilai kemampuan siswa menulis cerpen tanpa menggunakan media lagu diketahui bahwa nilai rata-rata $(\bar{X})$ siswa kelas kontrol adalah 7,2 Hasil nilai rata-rata tersebut dapat ditransformasikan ke dalam tabel klasifikasi kompetensi siswa kelas XI IPA 1 SMA Swasta Talaga Besar dalam menulis cerpen tanpa menggunakan media lagu dalam pembelajaran bahasa indonesia, maka nilai rata-rata kompetensi menulis cerpen tanpa menggunakan media lagu siswa kelas kontrol dikategorikan sedang. Hal ini terlihat pada tabel di atas yang menunjukkan bahwa nilai 7,6 berada pada rentang nilai 6,5 - 7,9 (kategori sedang). 


\section{SANG PENCERAH}

Volume 4, Nomor 2, Agustus 2018, Hlm. 21-27

Kosilah: Evektifitas Media Lagu dalam Pembelajaran ...

\section{Keefektifan Media Lagu dalam Pembelajaran Menulis Cerpen oleh Siswa Kelas XI IPA SMA Swasta Talaga Besar}

Berdasarkan hasil analisis data tes kelas eksperimen dan kelas kontrol dapat diketahui keefektifan media lagu dalam meningkatkan kompetensi siswa kelas XI IPA SMA Swasta Talaga Besar dalam menulis cerpen, untuk menghitung besarnya keefektifan tersebut, Hipotesis yang diuji dengan statistik uji $t$ adalah media lagu efektif dalam pembelajaran menulis cerpen siswa kelas XI IPA SMA Swasta Talaga Besar. Hipotesis ini adalah hipotesis alternatif $\left(\mathrm{H}_{\mathrm{a}}\right)$ Dalam penelitian ini, terungkap bahwa kelompok siswa yang menggunakan media lagu dalam pembelajaran menulis cerpen memiliki nilai yang tinggi, maka pengetesan yang digunakan adalah pengetesan satu arah. Dalam pengujian statistik, hipotesis ini dinyatakan sebagai berikut:

$$
\begin{gathered}
\mathrm{H}_{0}: t h<t \text { (terima) lawan } \mathrm{H}_{0} \text { : } \\
\text { th }
\end{gathered}
$$

Setelah diadakan perhitungan berdasarkan hasil statistik inferensial (eksperimen) jenis uji $\mathrm{t}$ diperoleh nilai $\mathrm{t}$ hitung: 1,78 dan d.b $=58$ dengan signifikansi $5 \%$ dan taraf kepercayaan 95\% maka nilainya adalah 1,67 (lihat pada lampiran distribusit). Kriteria pengujiannya adalah: $\mathrm{H}_{0}$ diterima jika $t_{\text {hitung }}<t_{\text {tabel }}$ dan $\mathrm{H}_{0}$ ditolak jika $t_{\text {hitung }} \geq t_{\text {tabel. }}$.

Ternyata $t_{\text {hitung }}(1,78)>t_{\text {tabel }}(1,67)$.

Berdasarkan perhitungan di atas, maka $\mathrm{H}_{0}$ ditolak dan $\mathrm{H}_{0}$ (hipotesis penelitian) diterima. Dengan demikian, penggunaan media lagu efisien dalam pembelajaran menulis cerpen siswa kelas XI IPA SMA Swasta Talaga Besar. Dari hasil analisis data perbandingan skor rata-rata hasil tes siswa antara kelas eksperimen dan kelas kontrol dengan menggunakan rumus uji $t$, dapat diketahui nilai $t_{\text {hitung }}$ diperoleh sebesar 1,78 dengan frekuensi (d.b) sebesar 58 pada taraf signifikan $5 \%$ diperoleh $t \cdot s_{0,05}=1,67$. jadi $t_{\text {hitung }}$ $>t_{\text {tabel }}$. Karena $t_{\text {hitung }}>t_{\text {tabel }}$ pada taraf signifikan 5\%, maka hipotesis nol $\left(\mathrm{H}_{0}\right)$ ditolak dan hipotesis alternatif $\left(\mathrm{H}_{\mathrm{I}}\right)$ diterima Hal ini berarti bahwa media lagu efektif diterapkan dalam pembelajaran menulis cerpen siswa kelas XI IPA SMA Swasta Talaga Besar. Perbedaan nilai rata-rata yang tidak terlampau jauh antara kelas eksperimen dengan kelas kontrol yakni 8,8 dan 7,6 Dari hasil esai yakni "menulis cerpen" terlihat perbedaan yang tidak terlampau jauh signifikan antara kelas eksperimen dan kelas kontrol.

Kelas ekperimen, hampir semua sampel dapat menulis cerpen dengan memperhatikan unsur-unsur cerpen mulai dari tema, tokoh dan penokohan, alur, setting/latar, sudut pandang, bahasa/gaya bahasa, dan amanat. Kelas kontrol juga bergitu hanya ada bebrapa siswa yang belum mampu menulis cerpen dengan memperhatikan unsur-unsur cerpen mulai dari tema, tokoh dan penokohan, alur, setting/latar, sudut pandang, bahasa/gaya bahasa, dan amanat .Inilah yang membuktikan kelas eksperimen yang menulis cerpen dengan menggunakan media lagu dengan kelas kontrol yang menulis cerpen tanpa media lagu. Jadi dapat disimpulkan bahwa, media lagu efektif dalam pembelajaran menulis cerpen Siswa kelas XI IPA SMA Swasta Talaga Besar.

\section{Simpulan}

Simpulan penelitian ini bahwa hasil analisis data yang menghasilkan nilai thitung sebesar 1.78 dan nilai tabel dengan signifikansi 5\% dan d.b 58 sebesar 1,67 dapat dikatakan bahwa $t_{\text {hitung }}$ lebih besar dari $t_{\text {tabel }}$ $(1,78>1,67)$. Jadi, dapat disimpulkan bahwa media lagu efisien dalam pembelajaran menulis cerpen siswa kelas XI IPA SMA Swasta Talaga Besar. 


\section{SANG PENCERAH}

Volume 4, Nomor 2, Agustus 2018, Hlm. 21-27

Kosilah: Evektifitas Media Lagu dalam Pembelajaran ...

\section{Daftar Pustaka}

Akhadiah, Sabarti dkk.1998. Pembinaan Kemampuan Menulis Bahasa Indonesia. Jakarta: Erlangga.

Arief S. Sadiman, dkk. 1989. Media Pendidikan, Pengertian, Pengembangan dan Pemanfaatanya. Jakarta: Pustekom Dikbud \& CV. Rajawali.

Arikunto, Suharsimi. 1997. Prosedur Penelitian: Suatu Pendekatan Praktek. Jakarta: Rineka Cipta.

Arsyad, Azhar. 2002. Media Pembelajaran. Jakarta: PT Raja Grafindo Persada

Depdiknas. 2006. Kurikulum 2006 Stampetensi Mata Pelajaran Bahasa Indonesia Sekolah Menengah Atas dan Madrasa Aliyah. Jakarta: Balai Pustaka.

Djiwandono, M. Soenardi. 2008. Tes Bahasa Pegangan Bagi Pengajar Bahasa. Jakarta: PT Indeks.

Keraf, gorys. 2000. Diksi dan Gaya Bahasa. Jakarta: Gramedia Pustaka Media.

Nurgiantoro, Burhan. 1995. Penilaian dan Pengajaran Bahasa dan Sastra. Yogyakarta: BPFE.

S. Sadiman, Arief. 2007. Media Pendidikan Pengertian Pengembangan dan Pemanfaatannya. Jakarta: PT RajaGrafindo Persada.

Samadhy, Umar. 2002. Pembelajaran Menulis di SD dengan Pendekatan Proses Menulis. Lingua Artistika, 321-327.

Sumardjo, Jacob. 1986. Memahami Kesusastraan. Bandung: Angkasa.
Suparni. 1990. Penuntun Pelajaran Bahasa Indonesia. Bandung: Ganeca Exact.

Tarigan, Henry Guntur. 1993. Prinsip-Prinsip Dasar Metode Riset Pelajaran Pembelajaran Bahasa. Bandung: Angkasa.

Zubaedah, Enny. 2002. Pembelajaran Bahasa dan Sastra Indonesia di SD. Bahastra, Hal 67 